\title{
FIRE IN EASTERN NORTH AMERICAN OAK ECOSYSTEMS: FILLING THE GAPS
}

\section{J. Morgan Varner ${ }^{1,7 *}$, Mary A. Arthur ${ }^{2}$, Stacy L. Clark ${ }^{3}$, Daniel C. Dey ${ }^{4}$, Justin L. Hart ${ }^{5}$, and Callie J. Schweitzer ${ }^{6}$}

${ }^{1}$ Department of Forest Resources \& Environmental Conservation, Virginia Tech, 310 West Campus Drive, Blacksburg, Virginia 24061, USA

${ }^{2}$ Department of Forestry, University of Kentucky, 209 Thomas Poe Cooper Building, Lexington, Kentucky 40546, USA

${ }^{3}$ USDA Forest Service, Southern Research Station, 2431 Joe Johnson Drive, Room 274, Knoxville, Tennessee 37996-4563, USA

${ }^{4}$ USDA Forest Service, Northern Research Station, 202 Anheuser Busch Natural Resources Building, Columbia, Missouri 65211, USA

${ }^{5}$ Department of Geography, University of Alabama, 513 University Boulevard, Tuscaloosa, Alabama 35487, USA

${ }^{6}$ USDA Forest Service, Southern Research Station, 730-D Cook Avenue, Huntsville, Alabama 35801, USA

${ }^{7}$ Current address: USDA Forest Service, Pacific Northwest Research Station, Pacific Wildland Fire Sciences Laboratory, 400 North 34th street, Suite 201, Seattle, Washington 98103, USA

*Corresponding author: Tel.: +1-206-732-7889; e-mail: julianvarner@fs.fed.us

\section{ABSTRACT}

This special issue of Fire Ecology is focused on the fire ecology of eastern USA oak (Quercus L.) forests, woodlands, and savannas. The papers were presented as part of the Fifth Fire in Eastern Oak Forests Conference in Tuscaloosa, Alabama, USA, in 2015. The topic of fire in Eastern oak ecosystems is one that has received insufficient interest from the broader fire ecology community. Specific papers in this issue address the historical role of fire in the region, the response and adaptations

\section{RESUMEN}

Esta edición especial de Fire Ecology está enfocada en la ecología del fuego de los bosques, arbustales y sabanas de roble (Quercus spp. L.) del este de los EEUU. Los trabajos fueron presentados como una parte de la Quinta Conferencia en Bosques de Roble del Este en Tuscaloosa, Alabama, EEUU, en 2015. El tema fuego en los ecosistemas de roble del este es uno de los que ha recibido un escaso interés por parte de la mayoría de la comunidad de la ecólogos del fuego. Trabajos específicos en este tema abarcan el rol histórico del fuego en la región, la respuesta y 
of plant and animal species to fire and fuels treatments, and the future of these important ecosystems under a future of global change. We hope that this issue provokes future research on the past, present, and future of fire in eastern North American oak ecosystems. las adaptaciones de especies de plantas y animales, y el futuro de estos importantes ecosistemas bajo un futuro de cambio climático. Nosotros esperamos que este tema estimule futuras investigaciones referidas al pasado, presente y futuro del fuego en los ecosistemas de roble del este de Norte América.

Keywords: Eastern deciduous forest, fire effects, fire history, fire regimes, mesophication, prescribed fire, Quercus

Citation: Varner, J.M., M.A. Arthur, S.L. Clark, D.C. Dey, J.L. Hart, and C.J. Schweitzer. 2016. Fire in eastern North American oak ecosystems: filling the gaps. Fire Ecology 12(2): 1-6. doi: 10.4996/fireecology.1202001

Fire is an important process in eastern North American oak (Quercus L.) ecosystems, but its role has been understudied compared to many other fire-prone ecosystems, a gap that has important implications for management and conservation. In Braun's (1950) classic Deciduous Forests of Eastern North America, she devoted fewer than 20 of its 596 detailed pages to fire. We surveyed the approximately 191 research articles published in Fire Ecology from 2005 to 2015: only 11 ( $6 \%)$ were based in Eastern deciduous forest ecosystems. Outside of the pages of Fire Ecology and in more recent research, there is a diverse literature on fire behavior, effects, and fire-vegetation dynamics in Eastern deciduous forests (e.g., Brose et al. 2014, Stambaugh et al. 2015), but considerably less than in ecosystems of western North America and perhaps elsewhere. This special issue includes eight papers presented at the Fifth Fire in Eastern Oak Forests Conference (27 to 29 May 2015, University of Alabama, Tuscaloosa, USA) and is intended to increase awareness and understanding of the role, processes, and management applicability of fire in eastern North American oak ecosystems.

The literature contains approximately 100 records of fire history from the Eastern deciduous forests or central hardwood forests of eastern North America (Hart and Buchanan 2012; Figure 1). The theme elucidated by this body of research is that fires were a common part of this landscape prior to Euro-American settlement (circa 1650 to 1890), exemplified by the 1954 Buell and others article (this issue), introduced by Marc Abrams.. Fire return intervals as short as one to two years have been reported from sites in this region, along with a diversity of sites exhibiting frequent, infrequent, and fire-free histories (see review in Hart and Buchanan 2012). However, gaps exist in the literature. For example, no published fire history studies have been conducted in several large areas of the Eastern deciduous forest (e.g., central Illinois, Indiana, and Ohio) and little information exists along the margins of this landscape. Stambaugh and others (this issue) provide a fire history of two sites on the margins of the Eastern oak forests region (eastern Tennessee and eastern Oklahoma) and a provocative discussion of scale-dependence of these regimes. With this and other studies, we still lack finer detail on other elements of historical fire regimes, such as intensity, severity, seasonality, and spatial extent, among others. Each of these shortcomings has direct implications for the use of fire in forest management and our understanding of the ecology of contemporary Eastern oak landscapes (Matlack 2013, Stambaugh et al. 2015)

Several important changes occurred in Eastern oak forests in the late nineteenth and early twentieth centuries, due in part to wide- 


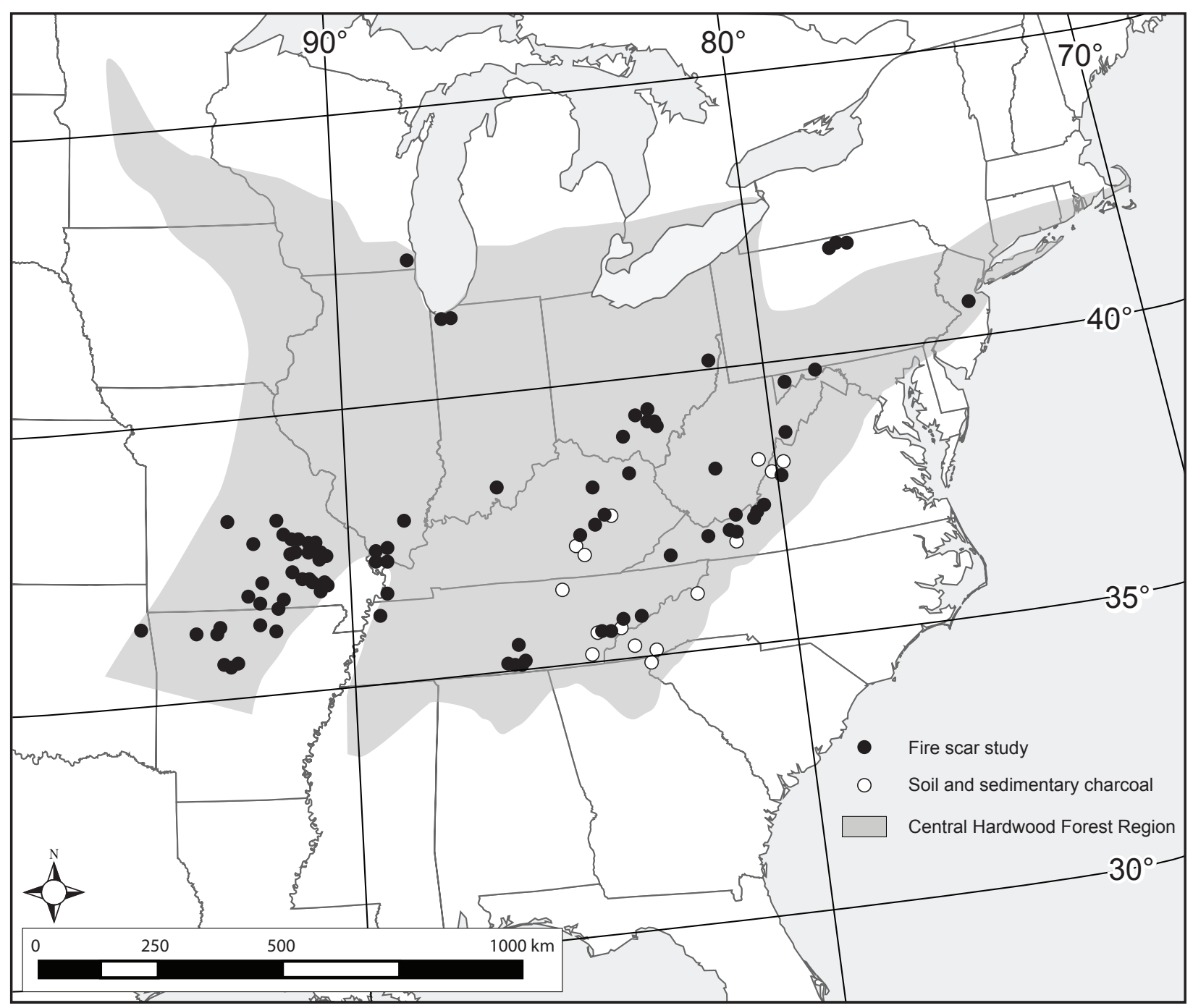

Figure 1. Distribution of fire history studies in eastern North America oak ecosystems (updated from Hart and Buchanan 2012).

spread fire exclusion that has further complicated contemporary ecosystem management and conservation. Perhaps the most apparent change has been landscape-level shifts in tree species composition from shade-intolerant (primarily oaks) to more shade-tolerant hardwoods, the so-termed "mesophication" phenomenon (Nowacki and Abrams 2008, Brose et al. 2014). This change has also been linked to global climate patterns, notably, the increase of precipitation in the twentieth century that further enhanced the expansion of mesophytic species and the losses and variation in keystone plant and animal species (McEwan et al.
2011). The most notable increase has been in maples (principally Acer rubrum L. and $A$. saccharum Marshall). Species composition changes have favored a microclimate that further dampened fuel flammability, reducing the ability of fire as a restoration and management tool across the region (Nowacki and Abrams 2008, Kreye et al. 2013). In the current disturbance and climate regime of reduced fire and increased moisture, the absence of stand-level disturbances favors more shade-tolerant species (i.e., maple), and shade-intolerant species with fast shoot growth potential (e.g., Liriodendron tulipifera L.) outcompete oaks fol- 
lowing canopy disturbances, particularly on higher quality sites (Johnson et al. 2009, Dey 2014). Hence, sustaining oak forests is one of the most important forest management challenges facing managers in eastern North America.

Long-term fire exclusion is responsible for noteworthy changes to ecosystem structure and function that negatively impact oak-dominated ecosystem quality, productivity, and sustainability. Due to the increases in forest density, oak savannas and woodlands have become some of the most endangered oak ecosystems in eastern North America (Dey and Kabrick 2016). The alterations in ecosystem structure and composition caused by increased tree density and maple dominance has resulted in declines in understory plant diversity, loss of ability to regenerate and sustain oak, shifts in animal communities, and alteration of ecosystem processes (Alexander and Arthur 2010, 2014; Brose et al. 2014; Stambaugh et al. 2015).

Brewer (this issue), Waldrop and others (this issue), and Schweitzer and others (this issue) discuss using fire and other silvicultural practices to halt or reverse plant community shifts across the region. Results indicate that fire restoration treatments should be used in conjunction with canopy openings to effectively increase the diversity and distinctiveness of groundcover vegetation in mixed oakpine (Pinus spp. L.) forests (Brewer, this issue), and to influence the development and recruitment of Quercus over Acer (Schweitzer et $a l$, this issue). Waldrop et al. (this issue) demonstrated that fire and mechanical treatments, applied repeatedly either alone or combined (fire + mechanical treatment), to a southern Appalachian site over 12 years led to increased oak reproduction in stands that approached the desired structure. In the Cumberland Plateau, Schweitzer and others (this issue) present findings on the effects of restoration treatments designed to shift planted pine-dominated forests to natural mixed oak- pine forests. These studies collectively identify hurdles to overcoming past fire exclusion and land-use changes, as well as the potential for fire to be incorporated in their restoration and management.

Plant and animal species have evolutionary adaptations to fire, and fire cessation has had effects on ecosystem structure, function, and processes. While other taxa have been investigated for their suites of fire-adapted traits (e.g., Keeley and Zedler 1998), considerably less research has focused on the protective, fire-facilitating, and physiological traits of oaks. Varner and others (this issue) discuss fire-adapted traits of Southeastern oaks, as well as oaks that lack such adaptations. Ford and others (this issue) discuss the responses of imperiled bats to fire in Eastern oak ecosystems. Harper and others (this issue) discuss animal responses to fire more broadly. Lastly, Vose and others (this issue) present plausible future predictions for Eastern oak ecosystems and how they might fare under current predictions of global change. A theme woven throughout each of these studies is that much is left unanswered about the influence of fire, and the management of fire, on past, current, and future Eastern oak ecosystems.

The lack of clarity in published research on prescribing fire in Eastern oak ecosystems is far from an academic issue. Restoration and conservation of these ecosystems face impediments to implementation and questions remain regarding fire's ability to restore or maintain desired processes and functions (Matlack 2013, Ryan et al. 2013). The ecological appropriateness of prescribed fire in the region has been debated more in terms of defining and achieving restoration objectives, and less in terms of a practical management tool to increase oak regeneration (McEwan et al. 2011, Arthur et al. 2012, Matlack 2013, Brose et al. 2014, Stambaugh et al. 2015). Filling in the gaps in our understanding of the ecology of oaks and their relationships with fire in eastern North American across the spectrum of oak 
habitats will help to clarify these issues (Arthur et al. 2012). Research that answers these questions and evaluates the role of fire as a management tool and an ecosystem process are clearly important. We hope that this spe- cial issue of Fire Ecology helps inspire focused investigation of fire ecology and management in oak-dominated ecosystems of eastern North America.

\section{LITERATURE CITED}

Alexander, H.D., and M.A. Arthur. 2010. Implications of a predicted shift from upland oaks to red maple on forest hydrology and nutrient availability. Canadian Journal of Forest Research 40: 716-726. doi: 10.1139/X10-029

Alexander, H.D., and M.A. Arthur. 2014. Increasing red maple leaf litter alters decomposition rates and nitrogen cycling in historically oak-dominated forests of the eastern US. Ecosystems 17: 1371-1383. doi: 10.1007/s10021-014-9802-4

Arthur, M.A., H.D. Alexander, D.C. Dey, C.J. Schweitzer, and D.L. Loftis. 2012. Refining the oak-fire hypothesis for management of oak-dominated forests of the eastern United States. Journal of Forestry 110: 257-266. doi: 10.5849/jof.11-080

Braun, E.L. 1950. Deciduous forests of eastern North America. Blackburn Press, Caldwell, New Jersey, USA.

Brose, P.H., D.C. Dey, and T.A. Waldrop. 2014. The fire-oak literature of eastern North America: synthesis and guidelines. USDA Forest Service General Technical Report NRS-135, Northern Research Station, Newtown Square, Pennsylvania, USA.

Dey, D.C. 2014. Sustaining oak forests in eastern North America: regeneration and recruitment, the pillars of sustainability. Forest Science 60: 926-942. doi: 10.5849/forsci.13-114

Dey, D.C., and J.M. Kabrick. 2016. Restoration of Midwestern oak woodlands and savannas. Pages 401-428 in: J.A. Stanturf, editor. Restoration of boreal and temperate forests. Second edition. CRC Press, Boca Raton, Florida, USA.

Hart, J.L., and M.L. Buchanan. 2012. History of fire in Eastern oak forests and implications for restoration. Pages 34-51 in: D.C. Dey, M.C. Stambaugh, S.L. Clark, and C.J. Schweitzer, editors. Proceedings of the 4th fire in Eastern oak forests conference. USDA Forest Service General Technical Report GTR-NRS-P-102, Northern Research Station, Newtown Square, Pennsylvania, USA.

Johnson, P.S., S.R. Shifley, and R. Rogers. 2009. The ecology and silviculture of oaks. Second edition. CABI Publishing, Boston, Massachusetts, USA. doi: 10.1079/9781845934743.0000

Keeley, J.E., and P.H. Zedler. 1998. Evolution of life histories in Pinus. Pages 219-251 in: D.M. Richardson, editor. Ecology and biogeography of Pinus. Cambridge University Press, England, United Kingdom.

Kreye, J.K., J.M. Varner, J.K. Hiers, and J. Mola. 2013. Toward a mechanism for eastern North American forest mesophication: the role of litter drying. Ecological Applications 23: 19761986. doi: 10.1890/13-0503.1

Matlack, G.R. 2013. Reassessment of the use of fire as a management tool in deciduous forests of eastern North America. Conservation Biology 27: 916-926. doi: 10.1111/cobi.12121

McEwan, R.W., J.M. Dyer, and N. Pederson. 2011. Multiple interacting ecosystem drivers: toward an encompassing hypothesis of oak forest dynamics across eastern North America. Ecography 34: 244-256. doi: 10.1111/j.1600-0587.2010.06390.x 
Nowacki, G.J., and M.D. Abrams. 2008. The demise of fire and "mesophication" of forests in the eastern United States. BioScience 58: 123-138. doi: 10.1641/B580207

Ryan, K.C., E.E. Knapp, and J.M. Varner. 2013. Prescribed fire in North American forests and woodlands: history, current practice, and challenges. Frontiers in Ecology and the Environment 11: e15-e24. doi: 10.1890/120329

Stambaugh, M.C., J.M. Varner, R.F. Noss, D.C. Dey, N. Christensen, R.F. Baldwin, R.P. Guyette, B. Hanberry, C. Harper, S. Lindblom, and T. Waldrop. 2015. Clarifying the role of fire in the Eastern deciduous forest: reply to Matlack. Conservation Biology 29: 942-946. doi: 10.1111/ cobi. 12473 